\title{
Using Small Group Discussion To Improve Students' Speaking Achievement At Smk Sore Pangkalpinang
}

\author{
Sinta $S^{1}$, Maya Saftari ${ }^{2}$ \\ ${ }^{1}$ ISB Atma Luhur \\ ${ }^{2}$ ISB Atma Luhur
}

Info Artikel :

Diterima 22 September 2020

Direvisi 7 Oktober 2020

Dipublikasikan 26 Oktober 2020

Keywords:
Improving
Speaking
Small group discussion

\section{Keywords}

Small group discussion

\begin{abstract}
ABSTRAK
The title of this study is "Using Small Group Discussion to improve Students' Speaking Achievement at SMK SORE Pangkalpinang.".The problems of this study :"Is small group Discussion effectively used in improving students' speaking achievement at SMK Sore Pangkalpinang?" The method of research used in this study was the experimental research. The type of experimental method used was quasi-experimental. The result of the test was analyzed by using SPSS Program. Based on the result of the data analysis, From the scores that were found, the result of statistical analysis between experimental and control group (t-obtained) should be higher than t-table (0.05) for two tailed. Furthermore the result of the students' score in control and experimental group (value of t-obtained) was 7.541. Since the value of t-obtained was higher than $\mathrm{t}$-table, so that the null hypothesis was rejected and alternative hypothesis was accepted. It can be stated that improving students' speaking achievement using small group discussion method is more effective than conventional way to students' at SMK SORE PANGKALPINANG.
\end{abstract}

\section{Koresponden:}

Sinta S, Maya Saftari

Email: s.sinta195@gmail.com, mayasaftari@atmaluhur.ac.id

\section{Introduction}

In our daily activities, we practice English never very confident. Especially in speaking class. The phenomenon is happened because we never practice it frequently. So that way we got hard to practice . As usual In speaking class, my students' still not talk active in English. This fact make me to find the best solution how can i give the best facilitate to my students' especially in teaching class. A foreign language is English learned by people who live in places where English is not the first language of the people who live in the country. The objective of teaching English is to develop the four languages skills (Reading, Listening, Speaking, Writing). In learning speaking, the lecturer will give variety activity how the students will speak up more. By giving them free activity to share their ideas in sepaking so it will make the class more excited. For example in speaking class we have excited activity like drama, presentation, poetry, speech, sing a song and many others.

English as a foreign language to Indonesian so it means that infers that speaking is only used in formal situation, when the student in a English Class. Literally they do it because some pressure to speak up. Sometime internal motivation still little to help them to speak in English, one of them is not very confidence or the students don't have self-confidence to exprees ideas in english as a foreign language. So the writer will apply small group discussion method in teaching speaking with many wishes that this learning method can help the students have self-confidence in speaking.

Small group discussion will improve students' speaking achievement minimally they can survive to speak in English class. Then the writer will give reward on it. So the students' must be brave to speak. It will improve their speaking achievement. Small group discussions are a great way to get students to engage with each other without the fear of having to address a large group. Often times there are one or two students in the group who feel comfortable addressing the larger group and some who wish to participate in discussion without the pressure of public speaking. Breaking students into groups is a great way to leverage this. Small group discussion make the students excited to express their ideas in speaking. firstly in using small group discussion. 
Based on the description above, the writer would like to research entitled "Using small group discussion to improve students' speaking achievement at SMK SORE PANGKALPINANG BANGKA BELITUNG".

\section{Literature Review \\ Speaking Achievement}

It can be said that "speaking" means making use of langauge in an ordinary, not singing, voices. Additionally, speaking is talking, back and forth. In this study the phrase learning to speak English refers to the acquiring of ability to utter English words orally and meaningfully. Speaking English is the main goal of many adult learners. Their personalities play a large role in determining how quickly and how correctly they will accomplish this goal. Those who are risk-takers unafraid of making mistakes will generally be more talkative, but many errors that could become hard-to-break habits. Conservative, shy students may take a long time to speak confidently, but when they do, their English often contains fewer errors and they will be proud of their English ability. It's a matter of quantity vs. quality, and neither approach is wrong. Speaking is the one of skills that should be taught in the class. The students learn to communicate each other by using their language they learn. The ability to speak, to give expression to one's need and feelings orally are a foundation for effective oral communication.

\section{Small Group Discussion}

According to Diane Larsen Freeman, "technique is the behavioral manifestation of the principles" Technique must be consistent with a method and therefore in harmony with an approach as well. According to Richard, technique is implementation which actually takes place in a classroom. It is a particular tricks, stratagem, or contrivance used to accomplish animmediate objective. Then, According to Brown, he defines that technique as any of a wide variety of exercises, activities, or tasks used in the language classroom for realizing lesson activities. Based on the explanation above, the researcher concluded that technique is a way of doing a lesson activities divided from an application of principle in the classroom. Technique must be consist with a method and therefore in harmony with an approach as well. Thus, small group discussion technique is one of the technique in teaching and learning writing because it is a teachers' technique which implemented in the classroom.

\section{Formulation at the Problem}

Based on the limitation problem above, the writer formulated the problems as follows: "Using Small Group Discussion to improve Students' Speaking Achievement at SMK SORE Pangkalpinang?"

\section{Objectives of the Study}

The objective of this study was to find out whether or not it is Using Small Group Discussion to improve Students' Speaking Achievement at SMK SORE Pangkalpinang.

\section{The Significances of the Study}

a. The writer could enlarge her knowledge and got experience in doing the research

b. 2. The result of this study could be of source information for help the teacher of English, the students, the readers and for the study to improve their speakings' achievement using small group discussion.

\section{Materials and Method}

The method of research used in this study was the experimental research. The type of experimental method used was quasi-experimental. Quasi experimental design This category of design is most frequently used when it is not feasible for the researcher to use random assignment. In this research, it has three basic characteristics: a control group is presented (2) the students are randomly selected and assigned to group and (3) a pretest is administrated to capture the initial difference between the group. Hatch and Fahrady (1982: 22) Issac and Michael (1980:14) describes that "the objective of true experimental is to investigate possible cause and effect relationship by exposing one or more experimental group to one or more treatment conditions and comparing the result to one or more control group not receiving treatment."The writer took 48 students for sample. 24 students as experimental group and 24 students as control group. The control group was taught using the techniques that was commonly used by the teacher at the school in teaching English. Meanwhile, the experimental some small groups consist of two students in one class was taught using dialogue activity. 


\section{Sample}

A sample is a set of individuals or objects collected or selected from a statistical population by a defined procedure. Sample is part of whole, population taken to show what the rest is like mention that sample is any number of things, students' event that are usually less than the total population. While Arikunto (2002:112), says that if the subject is less than 100, it's better to take it all, so that the experiment. If the subject was large, it can be taken between $10-15 \%$ or $20-25 \%$ or more. The sample of the study will be taken by random sampling method. Based on it, there are two classes got, that are XII AP and XII AK as my purposived sample. The first 24 students were classified as experimental group (class XII AK) and another 24 students were classified control group (class XII AP).

\section{Technique for collecting the data}

In this study, the writer used the test. Test was used to collect data on subject's ability or knowledge of certain disciplines. According to Arikunto (2006:59), a test is any series of question or exercise or other skill, knowledge, intelligence, capacities of attitude of an individual or group. In this study, the account of the test was four aspect. It consists of expression, pronunciation, vocabulary and fluency To improve the students' speaking ability through small group discussion method. Students will be able to create and practice the advertisiment that they got. The writer gave two test they were pre-test and post-test. Pre-test was given before the writer conducts the experiment. It was aimed to measure the students' speaking mastering before the experiment. Post-test was given at the end of the experiment. The objective of posttest was to know whether or not the treatment to be the experimental group had any significance differences in speaking mastery compared to the control group.

\section{Technique for analyzing data}

The techniques for analyzing data in this study were done through (1) percentage analysis (2) the conversion of the percentage ranges and (3) the matched t-test. The data analyzed is taken from the tests. The writer devides the students' scores into two groups. Group A: The scores of the pre-test and post-test of the students who learned speaking by using small group discussion. Groups B: The scores of the pre-test and post-test of the students who learned speaking by using traditional method. In this study, the writer will present the data distrubution of each test of both two groups in the form of the raw score, then the writer will analyze the data statistically by Interrater reliability and SPSS Program.

\section{Percentage analysis}

To measure the students' speaking ability, the writer will classify the scoring from each speaking component in order to make it clear when the writer gives the score.

\section{Table. 1 The Classification of Scoring}

Speaking Component

\begin{tabular}{|c|c|c|c|c|}
\hline \multirow{2}{*}{$\begin{array}{c}\text { Point of } \\
\text { Score }\end{array}$} & \multicolumn{4}{|c|}{ Description } \\
\hline & Pronunciation & Fluency & Expression & Vocabulary \\
\hline $21-25$ & $\begin{array}{l}\text { It is only very slightly } \\
\text { influenced by mother } \\
\text { tongue. Two or three } \\
\text { errors. On a par with } \\
\text { an educated native } \\
\text { speaker. }\end{array}$ & $\begin{array}{l}\text { Speak without too great } \\
\text { an effort with a fairly } \\
\text { wide range of } \\
\text { expression. Only one or } \\
\text { two un natural pauses. }\end{array}$ & $\begin{array}{l}\text { No difficulty in } \\
\text { deciding the } \\
\text { intonation, he can } \\
\text { use different } \\
\text { intonation match } \\
\text { with the situation. }\end{array}$ & $\begin{array}{l}\text { He really understands } \\
\text { with the topic and it } \\
\text { ease to make a very } \\
\text { good dialogue with } \\
\text { minor grammatical } \\
\text { errors. }\end{array}$ \\
\hline
\end{tabular}


$16-20$

$$
\begin{aligned}
& \text { It is slightly } \\
& \text { influenced by mother } \\
& \text { tongue. A few errors. }
\end{aligned}
$$

$11-15$

It is influenced by mother tongue but a few serious errors. Some of which cause confusion.

\section{6-10 It is seriously} influenced by mother tongue. Occasionally, lead to misunderstanding.

$0-05$

Serious pronunciation error, very hard to undertand

\section{There are not too many unnatural pauses. \\ A few intonation errors, but not serious.}

Has to make an effort for much of time. Range of expression often limited.

Long pauses while he searches for the desired meaning. Limited range of expression.

\section{Full of long and} unnatural pauses. Very limited range of expression.

Often make flat intonation. But, listener still understand.
Several intonation errors. Limited understanding in intonation.
Large number of intonation errors.
Know the topic, get the difficulty to make dialogue, several grammatical errors.

He understands with the topic and can make a good dialogue. A few grammatical errors.

Hard to understand the topic, make frequent errors in grammatical.
Failure to understand and to make himself understand.

\section{Source: Heatson, John Brian (1989: 98-100)}

Note: The point of score has category for each score. Point of 0 - 05 is Very Poor, $06-10$ is Poor, $11-15$ is Fair, $16-20$ is Good, $21-25$ is Very Good.

\section{Conversion of percentage range}

To interpret the students' individual score, the range that will be used as follows: very good, good, fair, poor, very poor. The score will be taken from the total of speaking component score:

Table. 2 Speaking Component Score

\begin{tabular}{|l|c|}
\hline Speaking Component & Score \\
\hline Pronunciation & 25 \\
Fluency & 25 \\
Expression & 25 \\
Vocabulary & 25 \\
Total & $\mathbf{1 0 0}$ \\
\hline
\end{tabular}

To interpret the quantitative score range written in students' report book as presented below:

Table. 3 Table Percentage of Score

\begin{tabular}{|c|c|c|}
\hline Percentage of score & Grade & Level of students competency \\
\hline $80-100$ & A & Excellent \\
$7-79$ & B & Good \\
$55-69$ & C & Fair \\
$45-54$ & D & Poor \\
$<44$ & E & Very poor \\
\hline
\end{tabular}




\section{Result and Discussion}

According to the result of test, in this study, the researcher tried to find out the comparison of result score between control group and experimental group. The comparison of score post-test in control group and experimental group was analyzed by using independent sample test.

Table. 4 Pair Sample Statistics of Control and

\section{Ex Class}

Group Statistics

\begin{tabular}{|c|c|c|c|c|c|}
\hline & CLASS & $\mathrm{N}$ & Mean & Std. Deviation & Std. Error Mean \\
\hline \multirow[t]{2}{*}{ RESULT } & $\mathrm{CC}$ & 24 & 66.3750 & 6.71023 & 1.36972 \\
\hline & $\mathrm{EC}$ & 24 & 86.3750 & 6.71023 & 1.36972 \\
\hline
\end{tabular}

Table. 5

\begin{tabular}{|c|c|c|c|c|c|c|c|c|c|}
\hline \multicolumn{10}{|l|}{ Independent Samples Test } \\
\hline & $\begin{array}{r}\text { Levene's } \\
\text { Equality of }\end{array}$ & $\begin{array}{l}\text { st for } \\
\text { ariances }\end{array}$ & \multicolumn{7}{|c|}{ t-test for Equality of Means } \\
\hline & \multirow[b]{2}{*}{$\mathrm{F}$} & \multirow[b]{2}{*}{ Sig. } & \multirow[b]{2}{*}{$\mathrm{t}$} & \multirow[b]{2}{*}{ Df } & \multirow[b]{2}{*}{$\begin{array}{l}\text { Sig. (2- } \\
\text { tailed) }\end{array}$} & \multirow[b]{2}{*}{$\begin{array}{c}\text { Mean } \\
\text { Difference }\end{array}$} & \multirow[b]{2}{*}{$\begin{array}{l}\text { Std. Error } \\
\text { Difference }\end{array}$} & \multicolumn{2}{|c|}{$\begin{array}{c}\text { 95\% Confidence } \\
\text { Interval of the } \\
\text { Difference } \\
\end{array}$} \\
\hline & & & & & & & & Lower & Upper \\
\hline $\begin{array}{c}\text { RESULT Equal variances } \\
\text { assumed }\end{array}$ & .000 & 1.000 & 7.541 & 46 & .000 & -20.00000 & 1.93708 & -23.89913 & -16.10087 \\
\hline $\begin{array}{l}\text { Equal variances not } \\
\text { assumed }\end{array}$ & & & 7.541 & 46.000 & .000 & -20.00000 & 1.93708 & -23.89913 & -16.10087 \\
\hline
\end{tabular}

Based on independent sample test, showed the value of t-obtained was 7.541. At the significant level $\mathrm{p}<0.05$ for two tailed test and degree of freedom was 46 , t-table was 1.99 as displayed in Table 5 .

\section{Interpretation}

Based on the statistical analysis, the result of statistical analysis between experimental and control group (tvalue) should be less than $t$-value (0.05) for two tailed. Furthermore the result of the students' score in control and experimental group (value of t-obtained) used independent sample test was 7.541 as showed in Table 5. Since the value of t-obtained was higher than t-table, so that the null hypothesis was rejected and alternative hypothesis was accepted. It can be stated that "Using small group discussion method through presentation of advertisiment to improve students' speaking achievement method is more effective than conventional way to the students at SMK SORE PANGKALPINANG BANGKA BELITUNG.

\section{Conclusion}

From the scores that were found, the result of statistical analysis between experimental and control group (t-obtained) should be higher than t-table (0.05) for two tailed. Furthermore the result of the students' score in control and experimental group (value of t-obtained) was 7.541. Since the value of t-obtained was higher 
than t-table, so that the null hypothesis was rejected and alternative hypothesis was accepted. It can be stated that "Using small group discussion method Using small group discussion method to improve students' speaking achievement is more effective than conventional way to the students at SMK SORE PANGKALPINANG BANGKA BELITUNG.

Using is more effective than conventional way to the students at SMK SORE PANGKALPINANG BANGKA BELITUNG.

In addition, the writer concluded that when she taught speaking class through conventional way. There are many students got the fair and good score is balanced or "good" and "fair" level and little students got excellent score. But when the writer taught speaking through small group discussion, there are so many students got excellent level and part of them got good level and there were no students got bad score or "fair" level. The point is they are happy and excited in speaking class using small group discussion, they have excellent self-confidence when they practiced.

\section{References}

Arikunto, Suharsimi. 1997. Prosedur Penelitian. Jakarta : Rineka Cipta.

Arikunto, Suharsimi. 2002. Prosedur Penelitian: Suatu Pendekatan Praktek. Jakarta : PT. Rineka Cipta.

Brown, Doglas, H. 1994. Teaching by Principles; An Interactive Approach to Language Pedagogy, San Francisco State University, Prentice Hall Regent Englewood Clifs, New Jersey.

Diane, Larsen. 2000. Freeman, Techniques and Principles in Language Teaching, New York: Oxford University Press.

Hatch, E, \& Farhady, H. 1982. Research Design and Statistic for Applied Linguistics. Los Angeles: New Houry Publisher

Heaton J.B. 1989. Writing English Language Tests, New York, the United State of America.

Isaac.S. dan Michael W.B. 1995. Handbook in research and evaluation: Acollection of principles, methods, and strategies useful in the planning, design, and evaluation of studies in education. Psynet.apa.org.

Jack C. Richard and Theodore S. Rodgers, 1989. Approaches and Method in Language Teaching, NewYork:Cambridge University Press

Jonathan Gibson, 2010. Small Group Teaching in English Literature: A Good Practice Guide, University of London: Royal Holoway. 